\title{
Free Thyroxine Estimation for the Screening of Hyper- and Hypothyroidism in an Adult Population
}

\author{
Hiroshi Fukazawa, Toshiro Sakurada, Katsumi \\ Yoshida, Hirofumi Kitaoka, Takashi Nomura, Michiko \\ Suzuki, Nobuko Kaise, Kazuro Kaise, Makiko \\ Yamamoto, Shintaro Saito and Kaoru Yoshinaga \\ The Second Department of Internal Medicine, Tohoku \\ University School of Medicine, Sendai 980
}

Furazawa, H., Sakurada, T., Yoshida, K., Kitaoka, H., Nomura, T., Suzuki, M., Kaise, N., Kaise, K., Yamamoto, M., Saito, S. and Yoshinaga, K. Free Thyroxine Estimation for the Screening of Hyper- and Hypothyroidism in an Adult Population. Tohoku J. exp. Med., 1986, 148 (4), 411-420 — Serum free thyroxine $\left(\mathrm{FT}_{4}\right)$, total $\mathrm{T}_{4}\left(\mathrm{~T}_{4}\right)$ and total $\mathrm{T}_{3}\left(\mathrm{~T}_{3}\right)$ were determined by radioimmunoassay in 1,114 adults during a periodic health evaluation to detect unsuspected thyroid dysfunction. As a result, 3 patients with hyperthyroidism, 4 with hypothyroidism, 3 taking thyroid medication, 4 with chronic thyroiditis, 1 with simple goiter and 3 women under estrogen administration were found. Free $\mathrm{T}_{4}$ values were within the normal limits in the present four subjects taking estrogens, but all of them showed high $\mathrm{T}_{4}$ and one high $\mathrm{T}_{3}$ values. $\mathrm{FT}_{4}$ and $\mathrm{T}_{4}$ were low in four patients with hypothyroidism, but two of them showed normal $\mathrm{T}_{3}$ values. For the screening of hyperthyroidism, $\mathrm{FT}_{4}$ was the most reliable measurement and determination of either $\mathrm{FT}_{4}$ or $\mathrm{T}_{4}$ was suitable for the screening of hypothyroidism, but $\mathrm{T}_{3}$ measurement did not diagnose all patients with hypothyroidism.

free thyroxine; thyroid dysfunction; mass-screening

Considerable evidence suggests that the concentration of serum free thyroxine $\left(\mathrm{FT}_{4}\right)$ is one of the best indices of the thyroid state. Recently, Remedios et al. (1980) proposed to add the $\mathrm{FT}_{4} \mathrm{I}$ (Clark and Horm 1965; Hamada et al. 1970), the product of serum total $\mathrm{T}_{4}$ and resin-sponge $\mathrm{T}_{3}$-uptake, to the multiphasic evaluation for the detection of unsuspected thyroid dysfunction. On the other hand, radioimmunoassay ( $\mathrm{RIA}$ ) have been developed to estimate the serum $\mathrm{FT}_{4}$ concentration in a routine basis.

The present paper describes the clinical significance of serum $\mathrm{FT}_{4}$ determination by RIA for the screening of hyper- and hypothyroidism in an adult population during a periodic health evaluation.

Received November 18, 1985 ; accepted for publication March 20, 1986. 


\section{Materials and Methods}

Blood samples were obtained from 1,114 participants during a periodic health examination in 1980. They were inhabitants in two towns in Miyagi prefecture, Japan (239 males, 875 females). Their ages ranged from 20 to 69 years. Serum thyroid hormones were measured by radioimmunoassay with commercially available kits. The normal ranges of these parameters are as follows : serum $\mathrm{FT}_{4}$ (GammaCoat two-steps $\mathrm{FT}_{4}$ kit, Clinical Assay, Cambridge, Mass, USA.), 0.68 to $2.0 \mathrm{ng} / 100 \mathrm{ml}$; serum total $\mathrm{T}_{4}\left(\mathrm{~T}_{4}, \mathrm{~T}_{4}\right.$-RIA kit, Clinical Assay), 4.5 to $11.5 \mu \mathrm{g} / 100 \mathrm{ml}$; and serum total $\mathrm{T}_{3}$ ( $\mathrm{T}_{3}, \mathrm{~T}_{3}$-RIA-II kit, Dainabot Co., Japan) ; 87 to $185 \mathrm{ng} / 100 \mathrm{ml}$, respectively.

If thyroid dysfunction was suspected by this screening, the following examinations were undertaken : radioactive iodine thyroid scan and determinations of serum thyroid stimulating hormones (TSH, H-TSH kit, Daiichi RI Lab., Tokyo ; normal, less than $8 \mu \mathrm{U}$ / $\mathrm{ml}$ ), serum thyroxine binding globulin (TBG) concentration (RIA-gnost TBG kit, Hoechst Co., Germany, normal range 13.6 to $31.6 \mu \mathrm{g} / \mathrm{ml})$, resin-sponge $\mathrm{T}_{3}$-uptake $\left(\mathrm{T}_{3}\right.$-RSU, Triosorb Test kit, Dainabot Co., normal range ; 25 to $35 \%$ ), 24-hr thyroid ${ }^{131}$ I-uptake (normal range ; 10 to $40 \%$ ), basal metabolic rate (BMR, normal range; $-10 \sim 15 \%$ ) and antithyroid antibodies. Anti-thyroid antibodies were determined with thyroglobulin and microsomal hemagglutination tests (MCHA and TGHA, Thyroid and Microsomal Tests, Fujizohki Co.). TGHA and MCHA were taken to be positive when titers are higher than $1: 100$.

In these subjects whose serum TSH values were higher than normal, thyrotropinreleasing hormone stimulating tests (TRH-test, $500 \mu \mathrm{g}$ TRH, i.v.) were performed.

In each subject with abnormal thyroid hormone values, the clinical signs and symptoms were also evaluated.

The data were analyzed for significance using Student's unpaired $t$ test, and $p<0.05$ was considered to be significant.

\section{Result}

Serum $\mathrm{FT}_{4}, \mathrm{~T}_{4}$ and $\mathrm{T}_{3}$ concentrations in normal subjects

As shown in Fig. 1, $\mathrm{FT}_{4}$ values of 1,096 euthyroid subjects showed a linear line on the logarithmic normal probability paper. Serum $\mathrm{T}_{4}$ and $\mathrm{T}_{3}$ of this group gave the same probability responses (data are not shown). Therefore, 95\% limits of the normal ranges of serum $\mathrm{FT}_{4}, \mathrm{~T}_{4}$ and $\mathrm{T}_{3}$ were determined to be from 0.60 to $1.80 \mathrm{ng} / 100 \mathrm{ml}, 6.0$ to $11.8 \mu \mathrm{g} / 100 \mathrm{ml}$ and from 84 to $176 \mathrm{ng} / 100 \mathrm{ml}$, respectively (Table 1).

Serum $\mathrm{FT}_{4}, T_{4}$ and $T_{3}$ concentrations in the diagnosis of hyperthyroidism

Out of 1,114 participants, there were 26,35 and 27 subjects who showed higher $\mathrm{FT}_{4}, \mathrm{~T}_{4}$ and $\mathrm{T}_{3}$ values than normal, respectively (Table $2 \mathrm{~A}$ and $2 \mathrm{~B}$ ).

By the subsequent detailed examinations for thyroid function mentioned above, three patients who showed high $\mathrm{T}_{3}, \mathrm{~T}_{4}$ and $\mathrm{FT}_{4}$ values were diagnosed as hyperthyroidism (Table 3). These three patients showed no response to TRH test (data not shown). Hyperthyroidism is finally judged from the elevations of serum $\mathrm{T}_{4}, \mathrm{FT}_{4}, \mathrm{~T}_{3}$ and $\mathrm{BMR}$ values, increased ${ }^{131} \mathrm{I}$-uptake ratio and the absence of the $\mathrm{TSH}$ response after intravenous $\mathrm{TRH}$ administration.

Of the 26 subjects whose $\mathrm{FT}_{4}$ values were higher than $1.81 \mathrm{ng} / 100 \mathrm{ml}$ (Table 


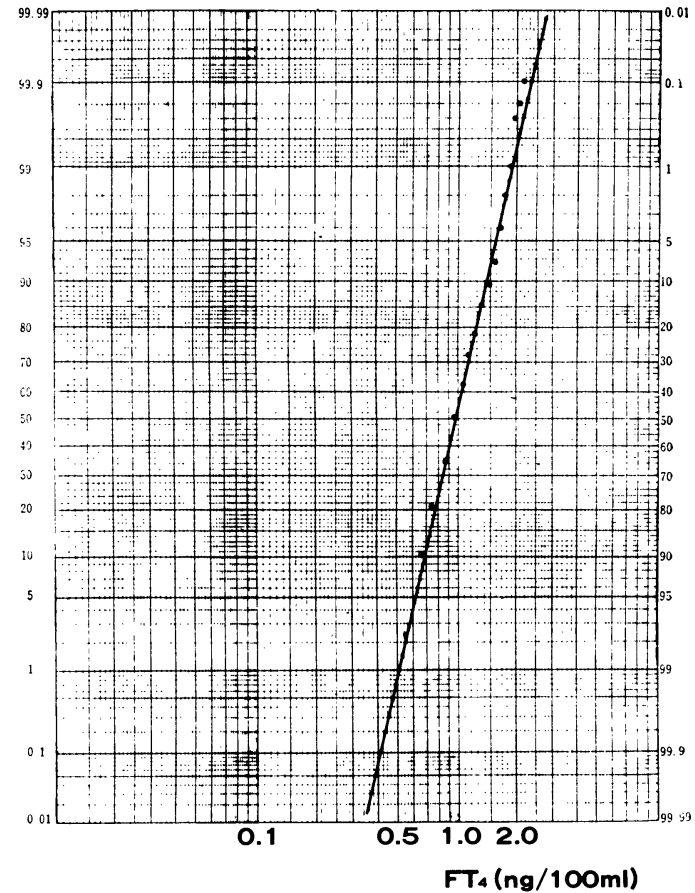

Fig. 1. Serum $\mathrm{FT}_{4}$ values of normal subjects on logarithmic normal probability paper.

TABLE 1. Mean and 95\% limits of serum $F T_{4}, T_{4}$ and $T_{3}$ in 1096 euthyroid subjects

\begin{tabular}{|c|c|c|c|c|}
\hline & \multicolumn{2}{|c|}{ Total } & Male & Female \\
\hline & Mean \pm S.D. & $95 \%$ limits & Mean \pm S.D. & Mean \pm S.D. \\
\hline $\mathrm{FT}_{4}(\mathrm{ng} / 100 \mathrm{ml})$ & $1.05 \pm 0.32$ & $0.60 \sim 1.80$ & $1.03 \pm 0.30$ & $1.06 \pm 0.32$ \\
\hline $\mathrm{T}_{4}(\mu \mathrm{g} / 100 \mathrm{ml})$ & $8.9 \pm 1.5$ & $6.0 \sim 11.8$ & $8.8 \pm 1.6$ & $9.0 \pm 1.5$ \\
\hline $\mathrm{T}_{3}(\mathrm{ng} / 100 \mathrm{ml})$ & $122 \pm 33$ & $\sim 176$ & $125 \pm 26$ & \pm 35 \\
\hline
\end{tabular}

$2 \mathrm{~A})$, there was one patient with chronic thyroiditis taking thyroxine.

Of the 35 cases who had higher total $\mathrm{T}_{4}$ than $11.9 \mu \mathrm{g} / 100 \mathrm{ml}$, there were three women taking estrogens, including contraceptive pills, five patients with chronic thyroiditis and two with simple goiter. Two of them with chronic thyroiditis and one with simple goiter were taking thyroxine.

Of the 27 subjects having $\mathrm{T}_{3}$ values higher than $177 \mathrm{ng} / 100 \mathrm{ml}$, one was taking estrogen and two were found to be treated with $\mathrm{T}_{4}$ (one patient with chronic thyroiditis and the other with simple goiter).

The three subjects taking estrogens had normal $\mathrm{FT}_{4}$ but $\mathrm{T}_{4}$ higher than normal values. As for the $\mathrm{T}_{3}$, one case showed high and the other two normal 
TABLE 2A. Distribution of serum $F T_{4}, T_{4}$ and $T_{3}$ levels in the 1,114 subjects

\begin{tabular}{|c|c|c|c|c|c|}
\hline \multicolumn{2}{|c|}{$\mathrm{FT}_{4}(\mathrm{ng} / 100 \mathrm{ml})$} & \multicolumn{2}{|c|}{$\mathrm{T}_{4}(\mu \mathrm{g} / 100 \mathrm{ml})$} & & $\mathrm{T}_{3}(\mathrm{ng} / 100 \mathrm{ml})$ \\
\hline & Cases $(\%)$ & & Cases $(\%)$ & & Cases $(\%)$ \\
\hline \multirow{9}{*}{$>1.81$} & \multirow{9}{*}{$26(2.3)$} & & & $>177$ & $4 \quad(0.4)$ \\
\hline & & $>11.9$ & $4 \quad(0.4)$ & $176 \sim 84$ & $0 \quad(\quad 0)$ \\
\hline & & & & $<83$ & $0 \quad(\quad 0)$ \\
\hline & & 11.8 & & $>177$ & $0 \quad(\quad 0)$ \\
\hline & & 1 & $22(2.0)$ & $176 \sim 84$ & $22 \quad(2.0)$ \\
\hline & & 6.0 & & $<83$ & $0 \quad(\quad 0)$ \\
\hline & & & & $>177$ & $0 \quad(0)$ \\
\hline & & $<5.9$ & $0(0)$ & $176 \sim 84$ & $0 \quad(\quad 0)$ \\
\hline & & & & $<83$ & $0 \quad(\quad 0)$ \\
\hline \multirow{9}{*}{$\begin{array}{l}1.80 \\
1 \\
0.60\end{array}$} & \multirow{9}{*}{$1,060(95.2)$} & & & $>177$ & $7 \quad(0.6)$ \\
\hline & & $>11.9$ & $31(2.8)$ & $176 \sim 84$ & $24 \quad(2.2)$ \\
\hline & & & & $<83$ & $0 \quad(\quad 0)$ \\
\hline & & 11.8 & & $>177$ & $15(1.3)$ \\
\hline & & 1 & $1,005(90.2)$ & $176 \sim 84$ & $970 \quad(87.1)$ \\
\hline & & 6.0 & & $<83$ & $20 \quad(1.8)$ \\
\hline & & & & $>177$ & $1 \quad(0.1)$ \\
\hline & & $<5.9$ & $24(2.2)$ & $176 \sim 84$ & $21 \quad(1.9)$ \\
\hline & & & & $<83$ & $2 \quad(0.2)$ \\
\hline \multirow{9}{*}{$<0.59$} & \multirow{9}{*}{$28(2.5)$} & & & $>177$ & $0 \quad(\quad 0)$ \\
\hline & & $>11.9$ & $0\left(\begin{array}{ll}0 \\
0\end{array}\right)$ & $176 \sim 84$ & $0 \quad(\quad 0)$ \\
\hline & & & & $<83$ & $0 \quad(\quad 0)$ \\
\hline & & 11.8 & & $>177$ & $0 \quad(\quad 0)$ \\
\hline & & 1 & $21(1.9)$ & $176 \sim 84$ & $21 \quad(1.9)$ \\
\hline & & 6.0 & & $<83$ & $0 \quad(\quad 0)$ \\
\hline & & & & $>177$ & $0 \quad(\quad 0)$ \\
\hline & & $<5.9$ & $7(0.6)$ & $176 \sim 84$ & $5 \quad(0.4)$ \\
\hline & & & & $<83$ & $2 \quad(0.2)$ \\
\hline
\end{tabular}

values.

Of the six patients with chronic thyroiditis, two cases were taking $\mathrm{T}_{4}$ and had high $\mathrm{T}_{4}$ values. In one of them, both $\mathrm{FT}_{4}$ and $\mathrm{T}_{3}$ were also high, but not in the other. In the remaining four patients with chronic thyroiditis taking no $\mathrm{T}_{4}$, all $\mathrm{FT}_{4}$ and $\mathrm{T}_{3}$ were within the normal ranges, but $\mathrm{T}_{4}$ was high in three and normal in one.

In two patients with simple goiter, the one taking $\mathrm{T}_{4}$ showed high $\mathrm{T}_{4}$ and $\mathrm{T}_{3}$ values but normal $\mathrm{FT}_{4}$, and the other with no $\mathrm{T}_{4}$ administration showed high $\mathrm{T}_{4}$ 


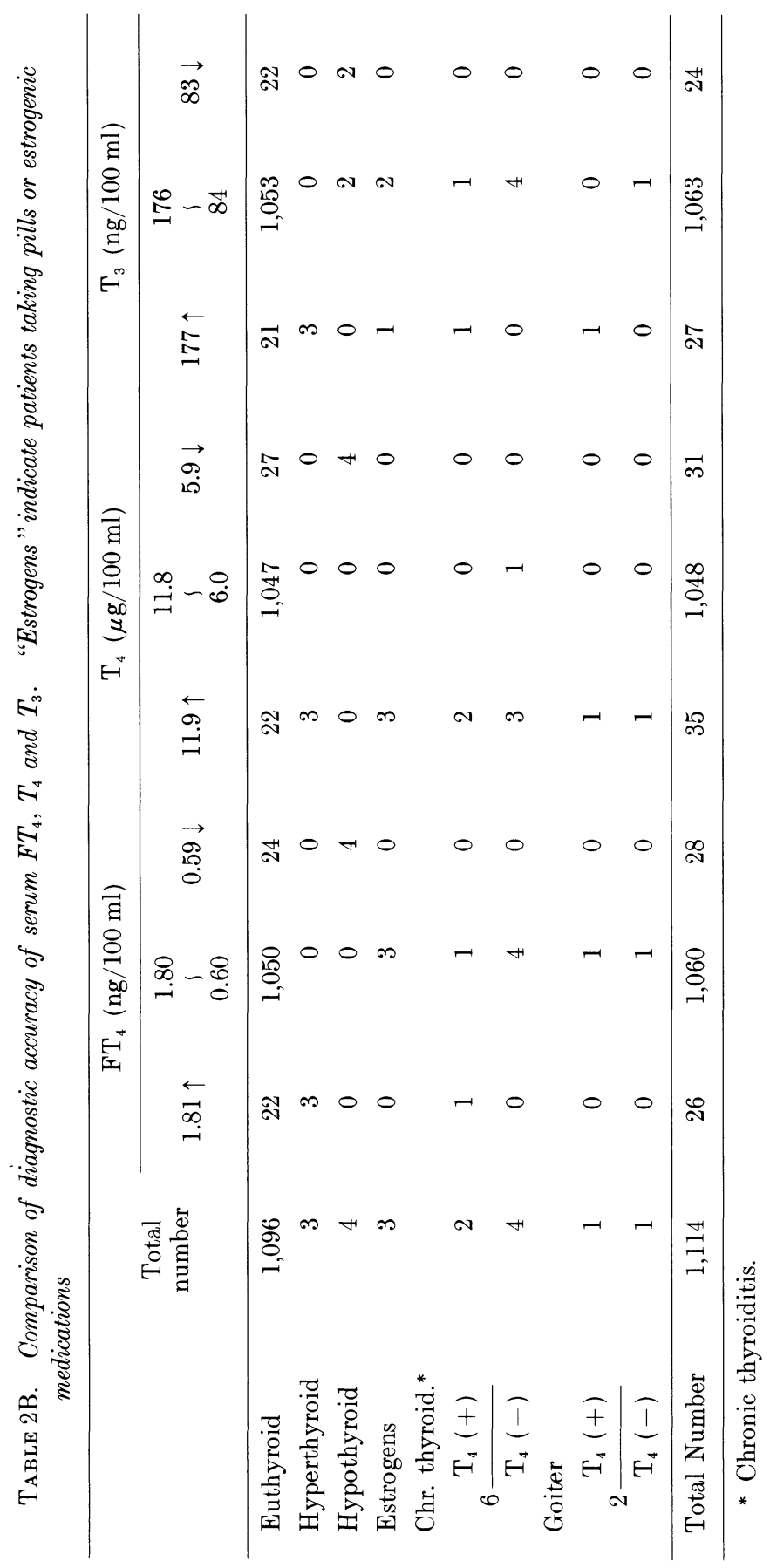




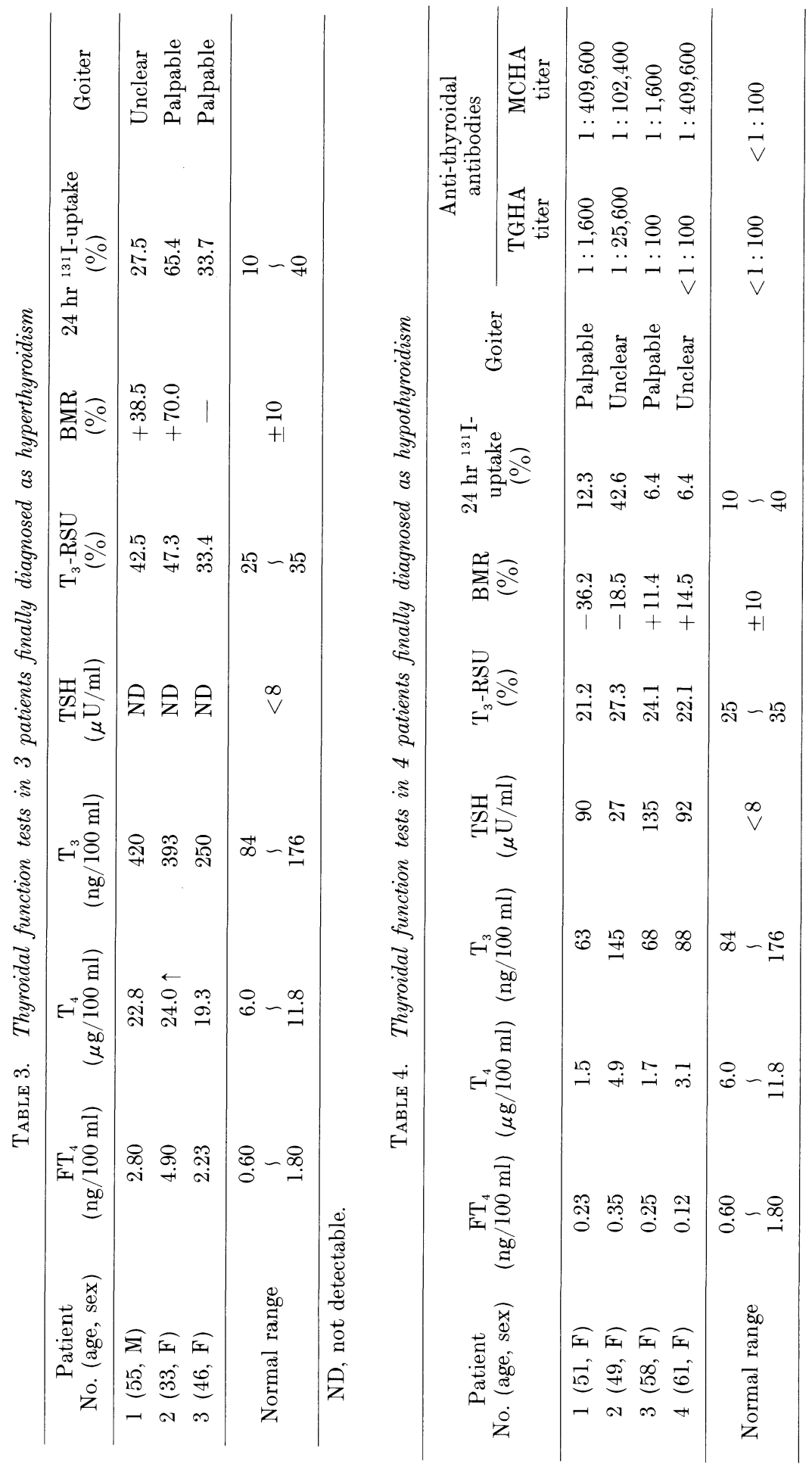


TABLE 5. Serum $F_{4}$ concentrations in different age group of both sexes

\begin{tabular}{ccccccc}
\hline \multirow{2}{*}{ Age } & \multicolumn{3}{c}{ Males } & \multicolumn{3}{c}{ Females } \\
\cline { 2 - 7 } & $\begin{array}{c}\text { Mean } \\
(\mathrm{ng} / 100 \mathrm{ml})\end{array}$ & S.D. & $\begin{array}{c}\text { Number } \\
\text { examined }\end{array}$ & $\begin{array}{c}\text { Mean } \\
(\mathrm{ng} / 100 \mathrm{ml})\end{array}$ & S.D. & $\begin{array}{c}\text { Number } \\
\text { examined }\end{array}$ \\
\hline $20 \sim 29$ & 0.81 & 0.30 & 2 & 0.96 & 0.22 & 20 \\
$30 \sim 39$ & 1.24 & 0.38 & 7 & 0.99 & 0.30 & 38 \\
$40 \sim 49$ & 1.02 & 0.29 & 85 & 1.05 & 0.33 & 281 \\
$50 \sim 59$ & 1.03 & 0.30 & 89 & 1.08 & 0.32 & 399 \\
$60 \sim 69$ & 1.03 & 0.33 & 53 & 1.07 & 0.32 & 122 \\
\hline $20 \sim 69$ & 1.03 & 0.30 & 236 & 1.06 & 0.32 & 860 \\
\hline
\end{tabular}

but normal $\mathrm{FT}_{4}$ and $\mathrm{T}_{3}$ values.

Consequently, there were ten cases with high $\mathrm{T}_{4}$, three with high $\mathrm{T}_{3}$ but only one with high $\mathrm{FT}_{4}$ in women taking estrogen, patients with chronic thyroiditis and those with simple goiter.

\section{Serum $\mathrm{FT}_{4}, \mathrm{~T}_{4}$ and $T_{3}$ concentration in the diagnosis of hypothyroidism}

Out of 1,114 adults screened, 28, 31 and 24 subjects showed lower $\mathrm{FT}_{4}, \mathrm{~T}_{4}$ and $\mathrm{T}_{3}$ values than normal, respectively (Table $2 \mathrm{~A}$ and $2 \mathrm{~B}$ ).

Further detailed studies resulted in the diagnosis of four patients with hypothyroidism. All $\mathrm{FT}_{4}$ and $\mathrm{T}_{4}$ values were low in these four patients. $\mathrm{T}_{3}$ levels were normal in two but low in the remaining two (Table 4). And these four patients showed the delayed hyperresponse to TRH tests (data not shown). The serum $\mathrm{T}_{4}, \mathrm{FT}_{4}, \mathrm{~T}_{3}$ and $\mathrm{TSH}, \mathrm{BMR}$ and ${ }^{131} \mathrm{I}$-uptake values confirmed the diagnosis of primary hypothyroidism (Table 4).

In the other subjects who showed low $\mathrm{FT}_{4}, \mathrm{~T}_{4}$ or $\mathrm{T}_{3}$ value (Table $2 \mathrm{~A}$ and $2 \mathrm{~B}$ ), $\mathrm{T}_{3}$-RSU and TSH values were normal and antithyroid antibodies negative.

Serum $\mathrm{FT}_{4}$ concentration in different age groups in both sexes

As shown in Table 5, 1,096 euthyroid males and females were grouped into five decades according to their ages (20-29, 30-39, 40-49, 50-59 and 60-69). No significant differences were found in serum $\mathrm{FT}_{4}$ among any age-groups or between sexes.

\section{Discussion}

The present study was undertaken to select the reliable thyroid function test out of $\mathrm{T}_{4}, \mathrm{~T}_{3}$ and $\mathrm{FT}_{4}$ determinations to detect the unsuspected patients with hyper- or hypothyroidism from numerous participants during periodic health examination. Because it is necessary to minimize the number of patients reexamined from the economical stand point of view. On the other hand, TSHscreening in current use for the detection of hypothyroidism seems to be not 
suitable for the detection of hyperthyroidism, since there is no difference between TSH values in euthyroidism and in hyperthyroidism. Several RIA kits (Yoshida et al. 1980 ; Kitaoka 1981 ; Nakagawa et al. 1982 ; Suzuki et al. 1982) capable of measuring serum $\mathrm{FT}_{4}$ have recently become available. We measured $\mathrm{FT}_{4}$ by RIA for the screening of hyper- and hypothyroidism in 1,114 adults during a periodic health check up. The present study revealed that 1,096 subjects were euthyroid. Serum $\mathrm{FT}_{4}, \mathrm{~T}_{4}$ and $\mathrm{T}_{3}$ values in euthyroid subjects showed a distribution of logarithmic normal probability, similar to the results of the other serum chemical components such as uric acid and creatinine (Neuman 1968).

In the present study, free $\mathrm{T}_{4}$ values were not changed with age between $40-$ 69 years in agreement with similar data examining the $\mathrm{FT}_{4}$ index (Bernudez et al. 1975; Gregerman and Davis 1978). Meanwhile, Malvaux et al. (1966) reported that $\mathrm{FT}_{4}$ was decreased in adolescents as compared to adults. Although it was not significant, possibly owing to the limited number of subjects aged 20-49 years in the present study, $\mathrm{FT}_{4}$ tended to be increased in 50's compared to 20's and 60's compared to 30's in females, and decreased in 40's compared to 30 's in males.

Among 1,114 adults, there were 3 patients with hyperthyroidism (prevalence; $0.27 \%$ ) and 4 with hypothyroidism (prevalence; $0.36 \%$ ). When serum TSH levels were normal in the cases with low $\mathrm{FT}_{4}, \mathrm{~T}_{4}$ and/or $\mathrm{T}_{3}$, a TRH-test was not carried out in the present study. Therefore, there remains a possibility that they were in a state of subclinical hypothyroidism. Remedios et al. (1980) reported that there were 8 hyperthyroid $(0.31 \%)$ and 14 hypothyroid $(0.50 \%)$ patients in an apparently healthy population (2,704 adults) screened for unsuspected thyroid dysfunction using $\mathrm{FT}_{4} \mathrm{I}$ determination. Baldwin and Rowett (1978) observed that the incidence was $0.39 \%$ for hypothyroidism. On the other hand, higher incidences, such as $0.97 \%$ and $1.58 \%$ (Baldwin and Rowett 1978 ; Tunbridge et al. 1977), have been reported for hyperthyroidism and 1.04\% (Tunbridge et al. 1977) for hypothyroidism.

Recently extensive investigation has been made concerning the so-called "low $\mathrm{T}_{3}$ syndrome" in nonthyroidal illnesses. This syndrome may be the result of diminution in extrathyroidal conversion of $\mathrm{T}_{4}$ to $\mathrm{T}_{3}$ (Chopra et al. 1975). In low $\mathrm{T}_{3}$ syndrome, $\mathrm{FT}_{4}$ has been reported to be normal despite a low $\mathrm{FT}_{4} \mathrm{I}$ (Janni et al. 1981). In the present study, no case of apparent "low $\mathrm{T}_{3}$ syndrome" was found, since we examined the subjects at a periodic health evaluation. However, it is conceivable that free $\mathrm{T}_{4}$ measurements will be useful in the diagnosis of this syndrome, when low serum $\mathrm{T}_{3}$ values are found during screening for thyroid dysfunction.

As shown in Table 2B, in the patients with chronic thyroiditis or simple goiter, seven patients showed high $\mathrm{T}_{4}$, two high $\mathrm{T}_{3}$ and one high $\mathrm{FT}_{4}$ values with or without thyroxine administration. Total $\mathrm{T}_{4}$ and $\mathrm{T}_{3}$ values can be misleading if the patients have conditions that alter the concentration of thyroxine-binding proteins, such as pregnancy, estrogen administration (Utiger 1974), contraceptive 
pills, and hereditary abnormalities in TBG (Sakurada et al. 1974). Free $\mathrm{T}_{4}$ values were within the normal limits in the present four subjects taking estrogens, but all of them showed high $\mathrm{T}_{4}$ and one high $\mathrm{T}_{3}$ values. These results confirmed our previous observation (Yoshida et al. 1980) that the determination of $\mathrm{FT}_{4}$ by GammaCoat $\mathrm{FT}_{4}$ RIA kit was not influenced by the change in $\mathrm{TBG}$.

It is generally accepted that $\mathrm{FT}_{4} \mathrm{I}$ is a better index of thyroid status than total $\mathrm{T}_{4}$ and total $\mathrm{T}_{3}$ (Remedios et al. 1980). However, the $\mathrm{FT}_{4} \mathrm{I}$ determination requires the measurement of both total $\mathrm{T}_{4}$ and $\mathrm{T}_{3}$-RSU. In addition, there is a question of the efficacy of $\mathrm{FT}_{4} \mathrm{I}$ in patients with "low $\mathrm{T}_{3}$ syndrome" (Chopra et al. 1979).

Out of 1,114 subjects examined, the number of cases reexamined for higher or lower than normal values were $54(4.8 \%)$ with $\mathrm{FT}_{4}, 66(5.9 \%)$ with $\mathrm{T}_{4}$ and 51 $(4.6 \%)$ with $\mathrm{T}_{3}$. If the $\mathrm{T}_{3}$ values is taken as the first choice for the screening, two patients with hypothyroidism as shown in Table 4 will be missed, although the number of cases for reexamination was least. Normal $\mathrm{T}_{3}$ in patients with hypothyroidism is reported already in several papers (Lieblich and Utiger 1972 ; Chopra et al. 1973). The number of subjects for detailed reexamination was less when judged from $\mathrm{FT}_{4}$ than from $\mathrm{T}_{4}$.

In summary, determinations of serum $\mathrm{FT}_{4}$, total $\mathrm{T}_{4}$ and total $\mathrm{T}_{3}$ were all sufficient methods for screening for hyperthyroidism. In the case of hypothyroidism, serum total $\mathrm{T}_{3}$ measurement did not reveal all the patients with hypothyroidism.

We have shown that determination of $\mathrm{FT}_{4}$ by RIA is useful as an initial screening test for thyroid dysfunction.

\section{Acknowledgments}

We acknowledge the gift of GammaCoat $\mathrm{FT}_{4} \& \mathrm{~T}_{4}$ RIA kit from Travenol Co. and $\mathrm{T}_{3}$-RIA-II kit from Dainabot Co.

\section{References}

1) Baldwin, D.B. \& Rowett, D. (1978) Incidence of thyroid disorders in Conneticut. J. Amer. med. Ass., 239, 742-744.

2) Bernudez, F., Surks, M.I. \& Oppenheimer, J.H. (1975) High incidence of decreased serum triiodothyronine concentration in patients with nonthyroidal disease. J.clin. Endocr., 41, 27-40.

3) Chopra, I.J., Solomon, D.H. \& Chua Teco, G.N. (1973) Thyroxine: Just a prohormone or hormone too? J. clin. Endocr., 36, 1050-1057.

4) Chopra, I.J., Chopra, U., Smith, S.R., Reza, M. \& Solomon, D.H. (1975) Reciprocal changes in serum concentrations of $3,3^{\prime}, 5^{\prime}$-triiodothyronine (reverse $\mathrm{T}_{3}$ ) and $3,3^{\prime}$, 5-triiodothyronine $\left(\mathrm{T}_{3}\right)$ in systemic illness. J. clin. Endocr., 41, 1043-1049.

5) Chopra, I.J., Solomon, D.H., Hepner, G.W. \& Morgenstein, A.A. (1979) Misleadingly low free thyroxine index and usefulness of reverse triiodothyronine measurement in nonthyroidal illness. Ann. intern. Med., 90, 905-912.

6) Clark, F. \& Horm, B. (1965) Assessment of thyroid function by the combined use of the serum protein-bound iodine and resin uptake of ${ }^{131} \mathrm{I}$-triiodothyronine. J. clin. 
Endocr., 25, 39-45.

7) Gregerman, R.I. \& Davis, P.J. (1978) Effect of intrinsic and extrinsic variables on thyroid hormone economy. In: The Thyroid, 4th ed., edited by S.C. Werner \& S.H. Ingbar, Harper \& Row, New York, pp. 232-252.

8) Hamada, S., Nakagawa, T., Mori, T. \& Torizuka, K. (1970) Re-evaluation of thyroxine binding and free thyroxine in human serum by paper electrophoresis and equilibrium dialysis, and a new free thyroxine index. J.clin. Endocr., 31, 166-179.

9) Janni, A., D’Azzo, G., Craxi, A., Marozzi, P., LiPuma, M. \& Pinzello, G. (1981) Clinical effect of low $\mathrm{T}_{3}$ on liver function. In: The "Low $T_{3}$ Syndrome", Serno Symposium No. 40, edited by R. D. Hesch, Academic Press, London-New York, pp. 171-185.

10) Kitaoka, M., Sakurada, T., Yoshida, K., Fukazawa, H., Kaise, N., Kaise, K., Yamamoto, M. \& Saito, S. (1981) Measurement of serum total free $\mathrm{T}_{4}$ concentration by IMMO PHASE Free $\mathrm{T}_{4}$ RIA kit, Kakuigaku, 18, 361-370. (in Japanese with English abstract)

11) Lieblich, J. \& Utiger, R.D. (1972) Triiodothyronine radioimmunoassay. J. clin. Invest., 51, 157-166.

12) Malvaux, P., De Nayer, Ph., Beckers, C., Schrieck, H.G. \& De Visscher, M. (1966) Serum free thyroxine and thyroxine binding proteins in male adolescents. $J$. clin. Endocr., 26, 459-462.

13) Nakagawa, T., Matsumura, K., Nobuta, N. \& Taguchi, M. (1982) A peculiarity of a method of measuring various free-thyroxine-comparison of combining reaction. Hormone to Rinsho, 30, 9-13. (in Japanese with English abstract)

14) Neumann. G.J. (1968) The determination of normal ranges from routine laboratory data. Clin. Chem., 14, 979-988.

15) Remedios, V.D., Weber, P.M., Feldman, R., Schurr, D.A. \& Tsoi, T.G. (1980) Detecting unsuspected thyroid dysfunction by the free thyroxine index. Arch.intern. Med., 140, 1045-1049.

16) Sakurada, T., Yamaguchi, T., Yamamoto, M., Demura, R., Aida, M., Onodera, S., Yoshida, K., Saito, S., Ohouchi, H. \& Minakuchi, S. (1974) Effect of estrogen on serum total and free thyroxine and triiodothyronine in a thyroxine-binding-globulin deficient family. Tohoku J. exp. Med., 112, 35-46.

17) Suzuki, M., Yoshida, K., Sakurada, T., Kitaoka, H., Fukazawa, H., Kaise, N., Kaise, K., Yamamoto, M., Saito, S. \& Yoshinaga, K. (1982) Measurement of serum free $\mathrm{T}_{4}$ concentration by Amerlex Free $\mathrm{T}_{4}$ RIA kit. Igaku to Yakugaku, 7, 731-738. (Japanese)

18) Tunbridge, W.M.G., Evered, D.C., Hall, R., Appleton, D., Brewis, M., Clark, F., Grimley Evans, J., Young, E., Bird, T. \& Smith, P.A. (1977) The spectrum of thyroid disease in a community: The Whickham survey. Clin. Endocr., 7, 481-493.

19) Utiger, R.D. (1974) Serum triiodothyronine in man. Ann. Rev. Med., 25, 289-302.

20) Yoshida, K., Sakurada, T., Kitaoka, H., Fukazawa, H., Kaise, N., Kaise, K., Yamamoto, M., Saito, S. \& Yoshinaga, K. (1980) A solid-phase radioimmunoassay for free thyroxine in serum compared with equilibrium dialysis method. Tohoku J.exp. Med., 132, 375-383. 